\title{
Afebrile Seizures as Initial Symptom of Hypocalcemia Secondary to Hypoparathyroidism
}

Sir,

I have two comments on the interesting case report by Gkampeta et al. on 7.5-year-old female child presented with afebrile seizures as an initial symptom of hypocalcemia secondary to hypoparathyroidism. ${ }^{[1]}$

First, the authors mentioned that the absence of cardiac defects, absence of distinct facial features, and unremarkable medical history during neonatal period helped them exclude the diagnosis of DiGeorge syndrome (DGS) ${ }^{[1]}$ Nevertheless, I presume that DGS still represents an important differential diagnosis in the case in question necessitating appropriate workup. My assumption is based on the following point. It is obvious that DGS often presents with hypocalcemia during the neonatal period and it is associated with other characteristic features, including developmental delay, congenital heart anomalies, primary hypoparathyroidism, aplasia or hypoplasia of the thymus, and a dysmorphic face. ${ }^{[2]}$ Truly, the clinical features of DGS are highly variable between individuals; some have subtle findings, whereas others are severely affected. ${ }^{[3]}$
Although the presentation of hypocalcemia due to DGS is mainly seen during neonatal period, presentation later in life has been reported usually precipitated by extreme stress. ${ }^{[4]}$ Nearly $90 \%$ of the affected individuals have a deletion at the long arm of chromosome 22 and $80 \%-90 \%$ of those deletions are de novo mutations. ${ }^{[2,3]}$ Genetic testing for that deletion is considered an important hallmark in the workup for DGS. Regrettably, it was not done in the case in question. I presume that if that genetic testing was accomplished and it revealed that chromosomal deletion, the case in question would be dually advantageous. On one hand, it could be considered a novel case report in Greece, since afebrile seizures presenting as an early manifestation of hypoparathyroidism in DGS patient has not been reported in the pediatric literature so far. On the other hand, it would support the notion that in a child with hypocalcemia, considering the hypothesis of DGS, even if there are no other manifestations, is important both for clinical diagnosis and management and for genetic counseling. ${ }^{[5]}$ 
Second, it would be also appropriate to seek out other causes for the studied patient, including mitochondrial disorders (several of these associated with parathyroid dysfunction) or mutations in the calcium-sensing receptor.

\section{Financial support and sponsorship}

Nil.

\section{Conflicts of interest}

There are no conflicts of interest.

Mahmood Dhahir Al-Mendalawi

Department of Paediatrics, Al-Kindy College of Medicine, Baghdad University, Baghdad, Iraq

Address for correspondence: Prof. Mahmood Dhahir Al-Mendalawi,

P. O. Box: 55302, Baghdad Post Office, Baghdad, Iraq. E-mail: mdalmendalawi@yahoo.com

\section{REFERENCES}

1. Gkampeta A, Kouma E, Touliopoulou A, Aggelopoulos E, Vourti E. Afebrile seizures as initial symptom of hypocalcemia secondary to hypoparathyroidism. J Neurosci Rural Pract 2016;7 Suppl 1:S117-9.

2. Graesdal A, Surén P, Vadstrup S. DiGeorge syndrome. An underdiagnosed disease category with different clinical features. Tidsskr Nor Laegeforen 2001;121:3177-9.
3. Kar PS, Ogoe B, Poole R, Meeking D. Di-George syndrome presenting with hypocalcaemia in adulthood: Two case reports and a review. J Clin Pathol 2005;58:655-7.

4. Goldmuntz E. DiGeorge syndrome: New insights. Clin Perinatol 2005;32:963-78.

5. Simão I, Lourenço T, Lopes L, Ramos MP. First seizure as late presentation of velo-cardio-facial syndrome. J Pediatr Endocrinol Metab 2013;26:381-3.

This is an open access article distributed under the terms of the Creative Commons Attribution-NonCommercial-ShareAlike 3.0 License, which allows others to remix, tweak, and build upon the work non-commercially, as long as the author is credited and the new creations are licensed under the identical terms.

\begin{tabular}{|l|l|}
\hline \multicolumn{2}{|c|}{ Access this article online } \\
\hline Quick Response Code: & Website: \\
& \\
& www.ruralneuropractice.com \\
& \\
\end{tabular}

How to cite this article: Al-Mendalawi MD. Afebrile seizures as initial symptom of hypocalcemia secondary to hypoparathyroidism. J Neurosci Rural Pract 2017;8:486-7.

C 2017 Journal of Neurosciences in Rural Practice | Published by Wolters Kluwer - Medknow 